\title{
STUDI OPTIMASI PENENTUAN KADMIUM(II) SECARA VOLTAMMETRI STRIPPING ADSORPTIF
}

\author{
Deswati, Hamzar Suyani, Citra Buhatika \\ Jurusan Kimia FMIPA Unand Padang
}

\begin{abstract}
Study of optimation cadmium(II) by adsorptive stripping voltammetry has been done. The aim of this study to get optimum conditions for determination of $\mathrm{Cd}(\mathrm{II})$. Parameters were done : potential accumulation, time accumulation, $\mathrm{pH}$, supporting electrolite concentration and optimum of complex concentration. In this case, the optimum conditions were reached in potential accumulation $-0.7 \mathrm{~V}$, time accumulation 60 second, $\mathrm{pH} 7.0, \mathrm{NH}_{4} \mathrm{Cl} 0.12 \mathrm{M}$, calcon concentration $0.12 \mathrm{mM}$. In the optimum condition was obtained with the relative standard deviation was $4.61 \%$ for eight replicates, measurements of $0.01 \mathrm{ppm}$. The method was applied to the direct determination of Cd(II) in water around Batang Air Dingin Lubuk Minturun and Muara Padang. Concentration $\mathrm{Cd}(\mathrm{II})$ in sample was equal to $7.359 \mu \mathrm{g} / \mathrm{L}$ and $3.659 \mu \mathrm{g} / \mathrm{L}$ with recovery of $99.04 \%$.
\end{abstract}

Keywords: cadmiun, adsorptive, stripping, voltammetry

\section{PENDAHULUAN}

Unsur transisi seperti kadmium adalah contoh unsur yang banyak dipakai dalam kehidupan sehari-hari. Kadmium dipakai secara luas pada baterai dan industri pigmen. Kadmium terdapat di lingkungan berupa limbah yang dapat menghasilkan racun yang mengancam kehidupan manusia, hewan dan tumbuhan ${ }^{[1]}$. Penyebaran dapat terjadi lewat media air. Jadi, perlu dilakukan penelitian untuk mengetahui kadar kadmium yang aman bagi kehidupan.

Beberapa metoda yang dapat digunakan untuk menentukan kadar kadmium, diantaranya spektrofotometer UV-Vis, flame-AAS, GFAAS, fluoresensi sinar $\mathrm{X}^{[2,3,4,5]}$. Metoda yang digunakan untuk menentukan kadar kadmium kali ini adalah voltametri stripping adsorptif. Voltametri didasarkan pada analisis sampel dengan mengontrol potensial elektrolisis, mengukur arus yang dihasilkan sebagai akibat adanya ion logam yang tereduksi dan menempel pada permukaan elektroda ${ }^{[6]}$. Voltametri stripping merupakan analisis sampel dalam konsentrasi runut. Metoda ini dipilih karena batas deteksi yang rendah, spesifik dan selektif, harga murah, infrastruktur sederhana, kadar garam yang tinggi dalam sampel tidak menggangu ${ }^{[7,8]}$.
Pada metoda AdSV digunakan ligan untuk membentuk kompleks dengan analit. Dalam penentuan kadmium dengan metoda voltametri stripping adsorptif, ligan-ligan seperti PTT (5phenyl 1,2,4-triazol 3-tion), TPN (thymolphtalexone), xylenol orange, dan DMTD (2,5-dimercapto $1,3,4$ thiadiazole) telah dipelajari ${ }^{[9,10,11,12]}$. Pada percobaan kali ini, digunakan kalkon sebagai pengompleks untuk penentuan kadmium dengan metoda voltametri stripping adsorptif.

Karena keberadaan kadmium di alam dalam jumlah runut, maka diperlukan suatu metoda yang mempunyai selektifitas dan sensitifitas yang tinggi untuk mengidentifikasi logam tersebut. Metoda tersebut adalah voltametri stripping adsorptif.

Penelitian ini bertujuan untuk mencari kondisi optimum, antara lain potensial akumulasi, waktu akumulasi, $\mathrm{pH}$ larutan, konsentrasi $\mathrm{NH}_{4} \mathrm{Cl}$, dan konsentrasi kalkon optimum yang diperlukan untuk penentuan kadmium secara voltametri stripping adsorptif.

Dari hasil penelitian ini diharapkan dapat melengkapi informasi dasar dalam penentuan kadmium secara voltametri stripping adsorptif, sehingga dapat bermanfaat bagi mahasiswa, 
masyarakat, pemerintah dan berbagai industri yang menggunakan metoda ini nantinya.

\section{METODOLOGI}

\section{Alat dan Bahan}

Alat yang digunakan pada penelitian ini adalah Metrohm 797 Computrace dengan elektroda kerja HMDE (elektroda pembanding berupa $\mathrm{Ag} / \mathrm{AgCl} / \mathrm{KCl} 3 \mathrm{M}$, dan elektroda Pt sebagai elektroda pendukung, $\mathrm{pH}$ meter Griffin model 80 (Griffin \& George Loughborough, Inggris), dan neraca analitis Mettler AE 200 (Toledo OH-USA) serta peralatan gelas yang biasa digunakan di laboratorium.

Bahan-bahan yang digunakan pada penelitian ini adalah larutan standar $\mathrm{Cd}(\mathrm{II})$, pengompleks kalkon, elektrolit pendukung $\mathrm{NH}_{4} \mathrm{Cl}$, akuabides dan sampel.

\section{Prosedur}

\section{Pengaruh Potensial Akumulasi}

$10 \mathrm{~mL}$ larutan standar $\mathrm{Cd}(\mathrm{II}) \quad 0,01 \mathrm{ppm}$ dimasukkan ke dalam vessel voltameter, ditambahkan $10 \quad \mathrm{~mL} \quad \mathrm{NH}_{4} \mathrm{Cl}$ kemudian ditambahkan kalkon. Potensial deposisi diatur dari -0,3 sampai $-0,8 \mathrm{~V}$, dilakukan pengukuran untuk mendapatkan nilai arus puncak (Ip). Dialurkan kurva antara variasi potensial deposisi dengan arus puncak (Ip). Potensial deposisi dengan arus puncak optimum dipakai untuk kondisi selanjutnya.

\section{Pengaruh Waktu Akumulasi}

Dimasukkan $10 \mathrm{~mL}$ larutan standar Cd(II) 0,01 ppm ke dalam vessel voltameter, ditambahkan $10 \mathrm{~mL} \mathrm{NH}{ }_{4} \mathrm{Cl}$ kemudian ditambahkan kalkon. Diatur potensial akumulasi $-0,7 \mathrm{~V}$, diatur waktu deposisi dari 0 sampai 100 detik. Dilakukan pengukuran untuk mendapatkan nilai arus puncak (Ip). Dialurkan kurva antara variasi waktu deposisi dengan arus puncak (Ip). Waktu deposisi dengan arus puncak optimum dipakai untuk penyelidikan selanjutnya.

Pengaruh $p H$
Dimasukkan $10 \mathrm{~mL}$ larutan standar Cd(II) 0,01 ppm ke dalam vessel voltameter, ditambahkan $10 \mathrm{~mL} \mathrm{NH} \mathrm{NH}_{4} \mathrm{Cemudian}$ ditambahkan kalkon. Diatur $\mathrm{pH}$ dari 5 sampai 9. Diatur potensial deposisi $-0,7 \mathrm{~V}$ dan waktu deposisi 60 detik. Dilakukan pengukuran untuk mendapatkan nilai arus puncak (Ip). Dialurkan kurva antara variasi $\mathrm{pH}$ dengan arus puncak (Ip). $\mathrm{pH}$ dengan arus puncak optimum dipakai untuk penyelidikan selanjutnya.

\section{Pengaruh Konsentrasi $\mathrm{NH}_{4} \mathrm{Cl}$}

Dimasukkan $10 \mathrm{~mL}$ larutan standar Cd(II) 0,01 ppm ke dalam vessel voltameter, ditambahkan $10 \mathrm{~mL} \mathrm{NH}_{4} \mathrm{Cl}$ kemudian ditambahkan kalkon. Konsentrasi $\mathrm{NH}_{4} \mathrm{Cl}$ yang dipakai divariasikan dari 0,02 M sampai 0,2 M. Diatur potensial deposisi $-0,7 \mathrm{~V}$, waktu deposisi 60 detik pada $\mathrm{pH}$ 7. Dilakukan pengukuran untuk mendapatkan nilai arus puncak (Ip). Dialurkan kurva antara variasi konsentrasi $\mathrm{NH}_{4} \mathrm{Cl}$ dengan arus puncak (Ip). Konsentrasi elektrolit pendukung dengan arus puncak optimum dipakai untuk penyelidikan selanjutnya.

\section{Pengaruh Konsentrasi Kalkon}

Dimasukkan $10 \mathrm{~mL}$ larutan standar Cd(II) 10 ppm ke dalam vessel voltameter, ditambahkan $10 \mathrm{~mL} \mathrm{NH}_{4} \mathrm{Cl}$ kemudian ditambahkan kalkon. Konsentrasi kalkon yang dipakai divariasikan dari $0,02 \mathrm{mM}$ sampai $0,22 \mathrm{mM}$. Diatur potensial deposisi $-0,7 \mathrm{~V}$, waktu deposisi 60 detik, konsentrasi $\mathrm{NH}_{4} \mathrm{Cl} 0,12 \mathrm{M}$ dan $\mathrm{pH} 7$. Dilakukan pengukuran untuk mendapatkan nilai arus puncak (Ip). Dialurkan kurva antara variasi konsentrasi kalkon dengan arus puncak (Ip). Konsentrasi kalkon dengan arus puncak optimum dipakai untuk penyelidikan selanjutnya.

\section{Pengukuran Sampel}

Dimasukkan $10 \mathrm{~mL}$ larutan sampel ke dalam vessel voltameter, ditambahkan $10 \mathrm{~mL} \mathrm{NH}_{4} \mathrm{Cl}$, kemudian ditambahkan kalkon. Diatur potensial deposisi, waktu deposisi, $\mathrm{pH}$, konsentrasi elektrolit pendukung dan konsentrasi pengompleks sesuai dengan kondisi optimum yang didapatkan. Dilakukan pengukuran untuk mendapatkan nilai arus puncak (Ip). Pengukuran dengan menggunakan 
metoda standar adisi untuk mendapatkan konsentrasi kadmium dalam sampel.

\section{HASIL DAN PEMBAHASAN}

\section{Pengaruh Potensial Akumulasi}

Pada penelitian ini dilakukan pengaruh variasi potensial akumulasi terhadap arus puncak yang diuji pada rentang -0,3 sampai dengan $-0,8 \mathrm{~V}$ yang hasilnya dapat dilihat pada Gambar 1 .

Potensial akumulasi adalah potensial pada saat analit terdeposisi pada elektroda kerja. Pada kurva di atas dapat dilihat bahwa pada setiap variasi potensial akumulasi yang diuji, memberikan nilai arus puncak yang berbeda. Pada potensial akumulasi - $0,3 \mathrm{~V}$ sampai $-0,5 \mathrm{~V}$ kurva turun secara signifikan. Pada rentang potensial $-0,6$ sampai $-0,7 \mathrm{~V}$ kurva naik dan kemudian turun pada $-0,8$ V. Hal ini menunjukkan, terjadi proses deposisi kompleks analit pada permukaan elektroda kerja yang mencapai maksimum di $-0,7 \mathrm{~V}$. Potensial akumulasi $-0,7 \mathrm{~V}$ digunakan pada penentuan selanjutnya.

\section{Variasi Waktu Akumulasi}

Pada penelitian ini juga diamati pengaruh waktu akumulasi terhadap arus puncak yang diuji dengan memvariasikan waktu: 0, 20, 40, $60,80,100$ detik, hasilnya dapat dilihat pada Gambar 2.

Waktu akumulasi adalah waktu pada saat analit terdeposisi pada elektroda kerja. Makin lama waktu akumulasi, analit terdeposisi lebih kuat di elektroda. Secara teori, makin lama waktu akumulasi, maka makin banyak analit yang terdeposisi di elektroda. Pada waktu 0 dan 20 detik, tidak didapatkan arus puncak. Hal ini dimungkinkan belum adanya analit yang terdeposisi di elektroda kerja. tapi, pada waktu 60 detik didapatkan waktu optimum penyerapan analit di elektroda kerja, kemudian setelah 60 detik terjadi penurunan nilai arus puncak. Hal ini disebabkan karena makin lama waktu akumulasi, maka makin banyak analit terdeposisi ke elektroda kerja dan membuat elektroda semakin jenuh. Akibatnya, pada saat stripping tidak semua analit yang dilepas, sehingga arus yang dihasilkan juga lebih kecil.

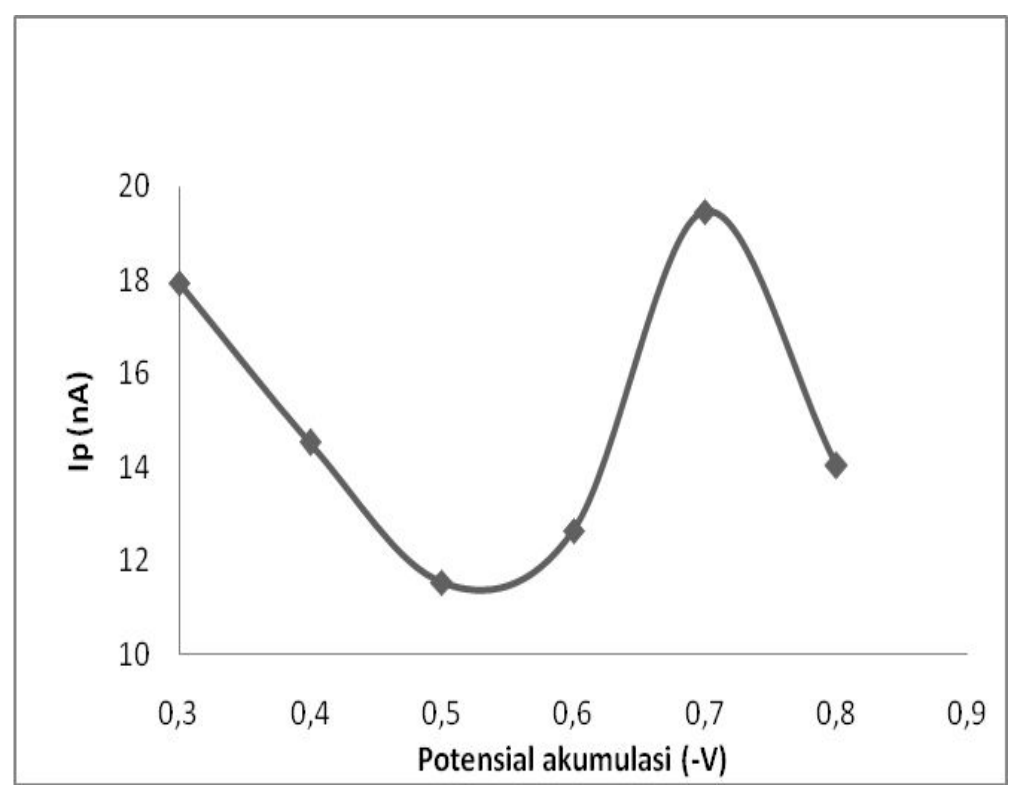

Gambar 1. Pengaruh potensial akumulasi (-V) terhadap arus puncak (Ip)

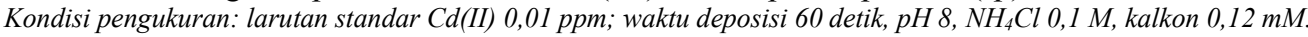




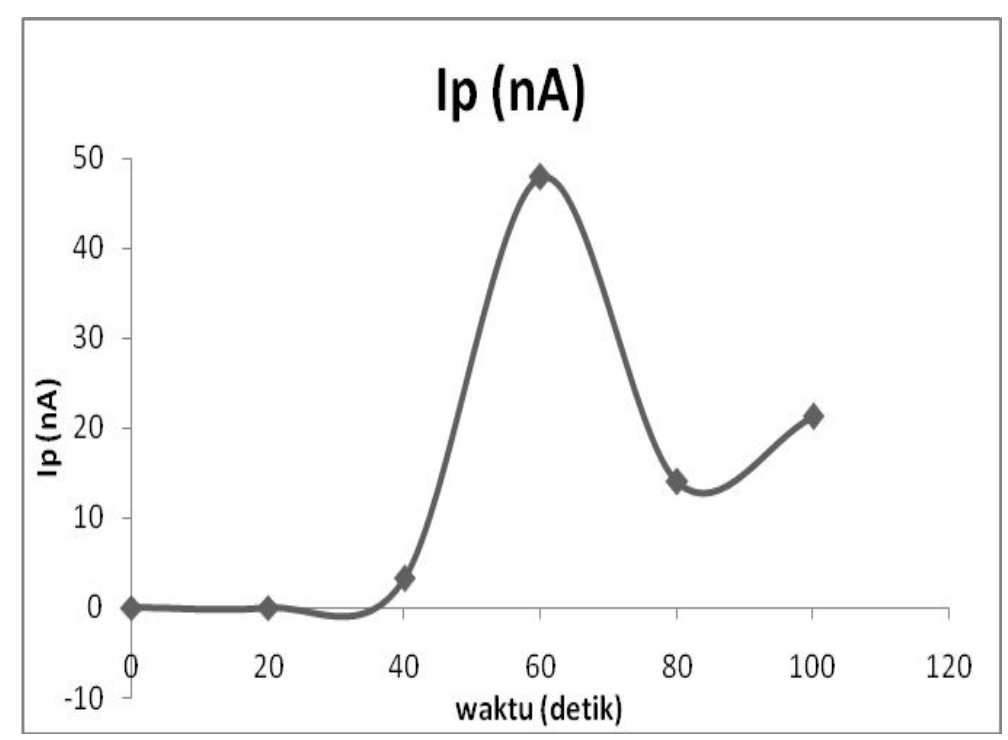

Gambar 2. Kurva waktu akumulasi (detik) Vs arus puncak (Ip)

Kondisi pengukuran: larutan standar Cd(II) 0,01 ppm, potensial deposisi -0,7 V, pH 8, $\mathrm{NH}_{4} \mathrm{Cl} \mathrm{0,1} \mathrm{M,} \mathrm{kalkon} \mathrm{0,12} \mathrm{mM.}$

\section{Pengaruh pH larutan}

Pada penelitian ini juga dilakukan pengaruh $\mathrm{pH}$ larutan terhadap arus puncak yang diuji dengan memvariasikan $\mathrm{pH}$ dari 5, 6, 7,8 sampai 9 yang hasilnya dapat dilihat pada Gambar 3.

$\mathrm{pH}$ sangat berperan dalam meningkatkan jumlah senyawa kompleks atau ion asosiasi yang terbentuk pada proses adsorpsi pada elektroda HMDE dan mempengaruhi kestabilan kompleks antara logam dengan ligan. Jika tidak sesuai, analit tidak terdeposisi sempurna di elektroda. Dari grafik dapat dilihat bahwa $\mathrm{pH}$ mengalami penurunan dari $\mathrm{pH} 5$ sampai $\mathrm{pH}$ 9. Tapi pada $\mathrm{pH} 7$ terjadi sedikit penyimpangan berupa kenaikan arus puncak. Ini dikarenakan pada $\mathrm{pH}$ tersebut logam dan ligan membentuk asosiasi ion dalam jumlah banyak. Bila $\mathrm{pH}$ larutan dibawah 7 atau pH optimum larutan lebih banyak mengandung ion $\mathrm{H}^{+}$akibatnya, terjadi kompetisi antara ion logam dengan ion $\mathrm{H}^{+}$untuk membentuk kompleks dengan kalkon. Bila $\mathrm{pH}$ larutan diatas $\mathrm{pH}$ optimum terjadi kelebihan $\mathrm{OH}^{-}$ dalam larutan akan memecah kompleks ligan logam sehingga adsorpsi ke elektroda akan berkurang, arus pun menjadi berkurang.

\section{Pengaruh Konsentrasi $\mathrm{NH}_{4} \mathrm{Cl}$}

Dalam penelitian ini dilakukan pengaruh konsentrasi $\mathrm{NH}_{4} \mathrm{Cl}$ terhadap arus puncak, yang diuji pada rentang 0,02 M sampai dengan 0.2 $M$ yang hasilnya dapat dilihat pada Gambar 4 .

$\mathrm{NH}_{4} \mathrm{Cl}$ berfungsi sebagai medium, menguatkan arus yang akan terbentuk, menambah selektifitas dari deposisi analit dan sebagai pelindung analit yang di analisis. Dari grafik dapat dilihat bahwa pada rentang konsentrasi 0,02 sampai $0,1 \mathrm{M}$ terjadi fluktuasi arus, mencapai maksimum pada konsentrasi $0,12 \mathrm{M}$. Ini dimungkinkan, pada konsentrasi $0,12 \mathrm{M}$ $\mathrm{NH}_{4} \mathrm{Cl}$ dapat menghantarkan analit ke elektroda secara maksimal. Sedangkan pada konsentrasi lebih besar arus puncak menurun.

\section{Pengaruh Konsentrasi Kalkon}

Dalam penelitian ini dilakukan pengaruh variasi konsentrasi pengompleks/kalkon terhadap arus puncak, yang diuji pada rentang konsentrasi $0,02 \mathrm{mM}$ sampai dengan $0.22 \mathrm{mM}$

Kestabilan kompleks antara kadmium dengan kalkon dipengaruhi oleh konsentrasi pengomplek itu sendiri. Dari Gambar 5 dapat dilihat dengan meningkatnya konsentrasi kalkon dibawah $0,12 \mathrm{mM}$, arus puncak yang dihasilkan juga meningkat. Dimana, didapatkan kondisi optimum pada konsentrasi kalkon $0,12 \mathrm{mM}$ yang memberikan arus 
puncak optimum. Pada konsentrasi pengompleks lebih kecil belum terjadi kompleks yang sempurna antara logam dan pengompleks sehingga arus yang didapat masih kecil. Pada konsentrasi optimum, logam dan pengompleks telah terkompleks dengan sempurna sehingga memberikan arus optimum.
Pada konsentrasi lebih besar dimungkinkan terjadi kompetisi antar pengompleks sebagai ligan dalam berikatan dengan ion logam sehingga arus menurun. Selain itu dimungkinkan terbentuk lapisan tebal di elektroda sehingga menghalangi terjadinya transfer elektron antara ion kadmium.

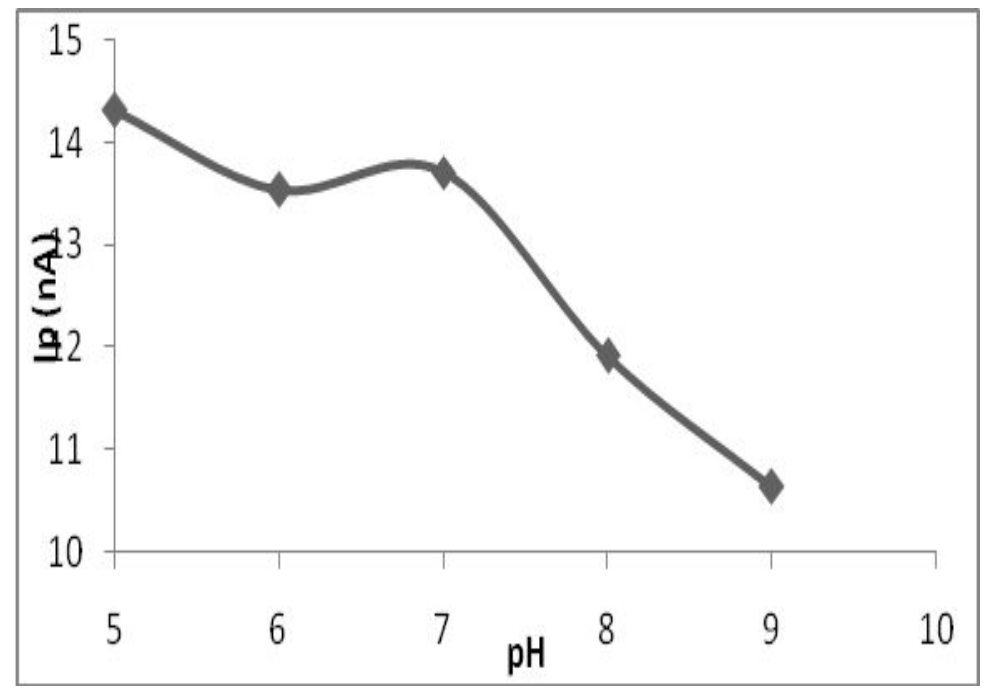

Gambar 3. Pengaruh $\mathrm{pH}$ terhadap arus puncak (Ip)

Kondisi pengukuran: larutan standar Cd(II) 0,01 ppm; potensial deposisi -0,7 V; waktu deposisi 60 detik; $\mathrm{NH}_{4} \mathrm{Cl}$ 0,1 M, kalkon 0,12 $\mathrm{mM}$

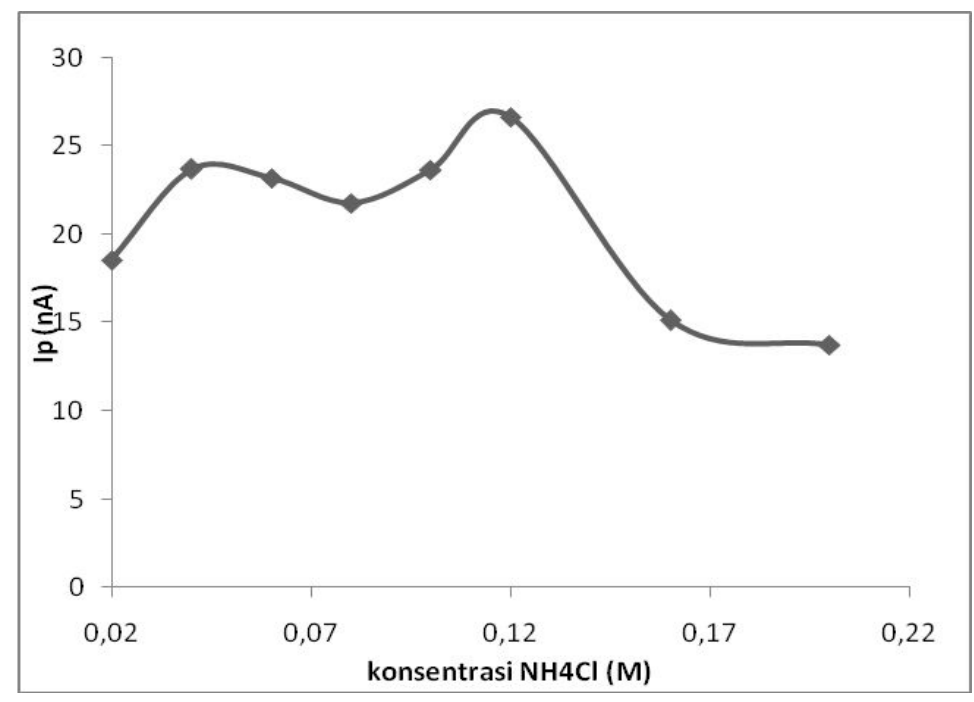

Gambar 4. Kurva konsentrasi $\mathrm{NH}_{4} \mathrm{Cl}$ vs arus puncak (Ip)

Kondisi pengukuran: larutan standar Cd(II) 0,01 ppm; potensial deposisi -0,7 V, waktu deposisi 60 detik, pH 7, kalkon 0,12 mM. 


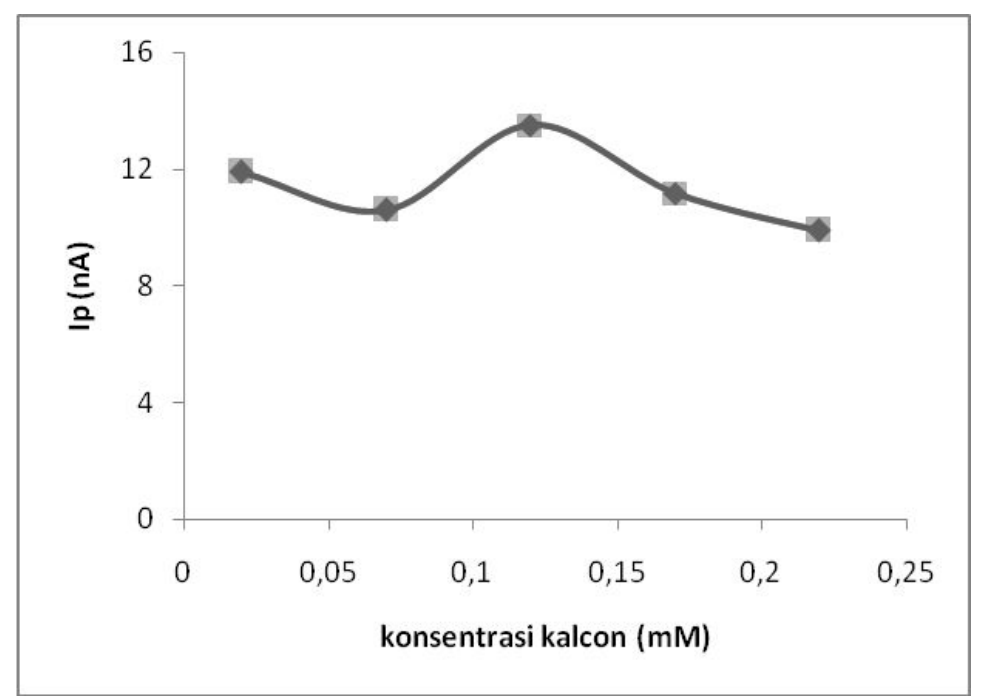

Gambar 5. Kurva konsentrasi kalkon vs arus puncak (Ip)

Kondisi pengukuran: larutan standar Cd(II) 0,01 ppm, potensial deposisi -0,7 V, waktu deposisi 60 detik, pH 7, $\mathrm{NH}_{4} \mathrm{Cl} 0,12 \mathrm{M}$

\section{Standar Deviasi Relatif (SDR)}

Standar deviasi relatif (SDR) digunakan untuk melihat ketelitian suatu metoda pada kondisi operasi yang sama dalam interval waktu yang tidak lama ${ }^{[13]}$. Penentuan standar deviasi relatif dilakukan pada konsentrasi larutan Cd(II) 0,01 ppm dengan 8 kali pengulangan. Sedangkan standar deviasi relatif metoda voltametri stripping adsorptif untuk larutan standar $\mathrm{Cd}(\mathrm{II})$ $0,01 \mathrm{ppm}$ didapatkan sebesar $4,61 \%$. Semakin kecil nilai SDR, maka semakin tinggi ketelitian dari metoda tersebut. Jadi bisa disimpulkan bahwa metoda ini sudah cukup teliti.

\section{Aplikasi Pada Sampel}

Aplikasi metoda ini dalam penentuan kadmium dilakukan pada sampel air Batang Air Dingin Lubuk Minturun dan Muara, Padang dengan menggunakan kondisi optimum pengukuran yang telah didapatkan, yaitu potensial akumulasi $-0,7 \mathrm{~V}$, waktu deposisi 60 detik, $\mathrm{pH}$ 7, konsentrasi $\mathrm{NH}_{4} \mathrm{Cl} 0,12 \mathrm{M}$ dan konsentrasi kalkon 0,12 mM. Pengukuran sampel dilakukan dengan menggunakan metoda standar adisi.

Gambar 6 dan 7 menunjukkan voltamogram pengukuran sampel air muara dan lubuk minturun dengan metoda standar adisi pada alat voltameter Metrohm 797 Computrace. Dari gambar dapat dilihat kenaikan arus puncak sampel dengan penambahan larutan standar kadmium 1 ppm sebanyak dua kali. Hal ini membuktikan bahwa pada sampel tersebut terdapat kadmium.

Konsentrasi sampel hulu dan sampel muara yang didapatkan dari kedua kurva standar adisi diatas adalah 7,359 ng/L dan 3,659 ng/L. Arus puncak yang didapatkan tidak jauh berbeda yaitu 1,76 nA untuk sampel Lubuk Minturun dan 1,04 nA untuk sampel muara (Gambar 8). Kandungan kadmium dalam sampel Muara lebih rendah dibandingkan sampel hulu. Padahal air muara lebih tercemar dibanding air lubuk minturun. Hal ini diperkirakan karena pada air muara telah terdapat berbagai kandungan senyawa kontaminan yang berasal dari limbah masyarakat. Sehingga terdapat interferensi senyawa kontaminan berupa deterjen atau senyawa aktif permukaan yang terkandung dalam air muara. Hal ini akan menyebabkan proses akumulasi kadmiumkalkon pada permukaan elektroda kerja menjadi terganggu karena elektroda kerja telah dipenuhi senyawa-senyawa interferensi tersebut, sehingga mempengaruhi arus puncak yang didapatkan.

\section{Perolehan Kembali}

Untuk mengetahui tingkat ketepatan metoda ini perlu dilakukan penentuan nilai perolehan kembali yang dilakukan dengan cara membandingkan konsentrasi sampel yang didapatkan dengan konsentrasi analit dalam 
sampel yang telah ditambahkan. Perolehan kembali dilakukan dengan cara mengukur sampel yang telah diketahui konsentrasinya sebanyak $10 \mathrm{~mL}$ yang kemudian ditambahkan dengan menggunakan larutan standar $\mathrm{Cd}$ (II) 2 , 4 dan $6 \mathrm{ng} / \mathrm{L}$. Hasilnya dapat dilihat pada Tabel 1.

\section{KESIMPULAN}

Dari hasil penelitian yang telah dilakukan dapat disimpulkan bahwa potensial akumulasi
$-0,7 \mathrm{~V}$, waktu akumulasi 60 detik, pada $\mathrm{pH}$ larutan 7, konsentrasi $\mathrm{NH}_{4} \mathrm{Cl} \quad 0,12 \mathrm{M}$ dan konsentrasi kalkon $0,12 \mathrm{mM}$ digunakan sebagai kondisi optimum dalam penentuan kadmium secara voltametri stripping adsortif. Aplikasi metoda AdSV penentuan konsentrasi kadmium dalam sampel Batang Air Dingin Lubuk Minturun dan Muara, Padang adalah 7,359 $\mathrm{ng} / \mathrm{L}$ dan 3,659 $\mathrm{ng} / \mathrm{L}$ dengan nilai perolehan kembali 99,04 \%.

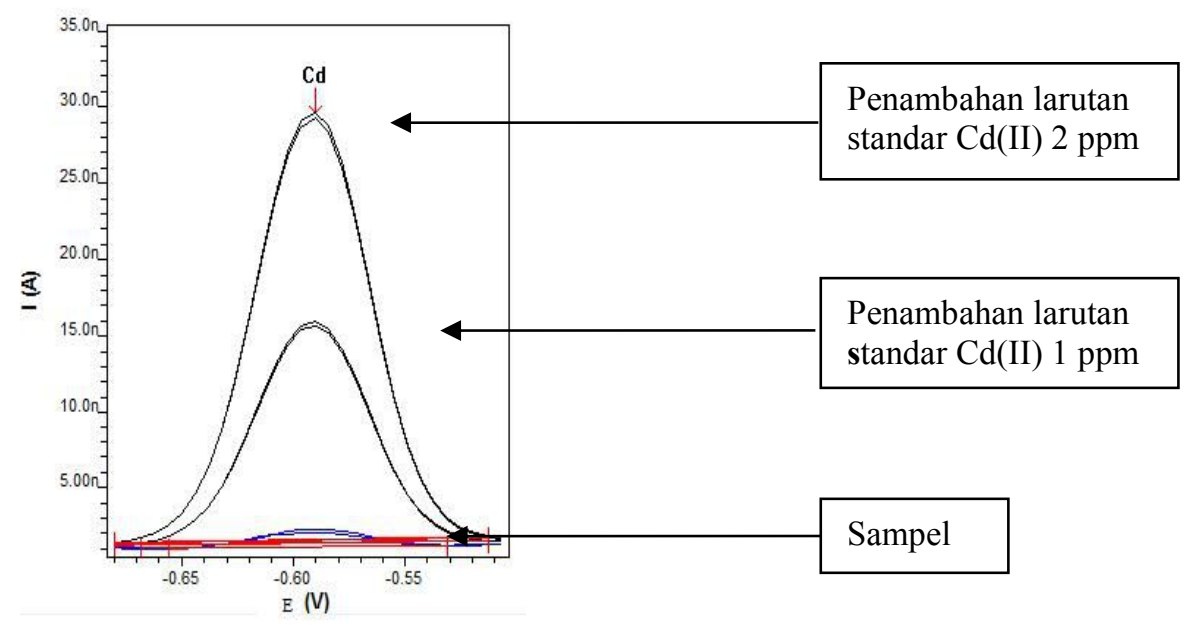

Gambar 6. Voltamogram sampel air muara dengan metoda standar adisi

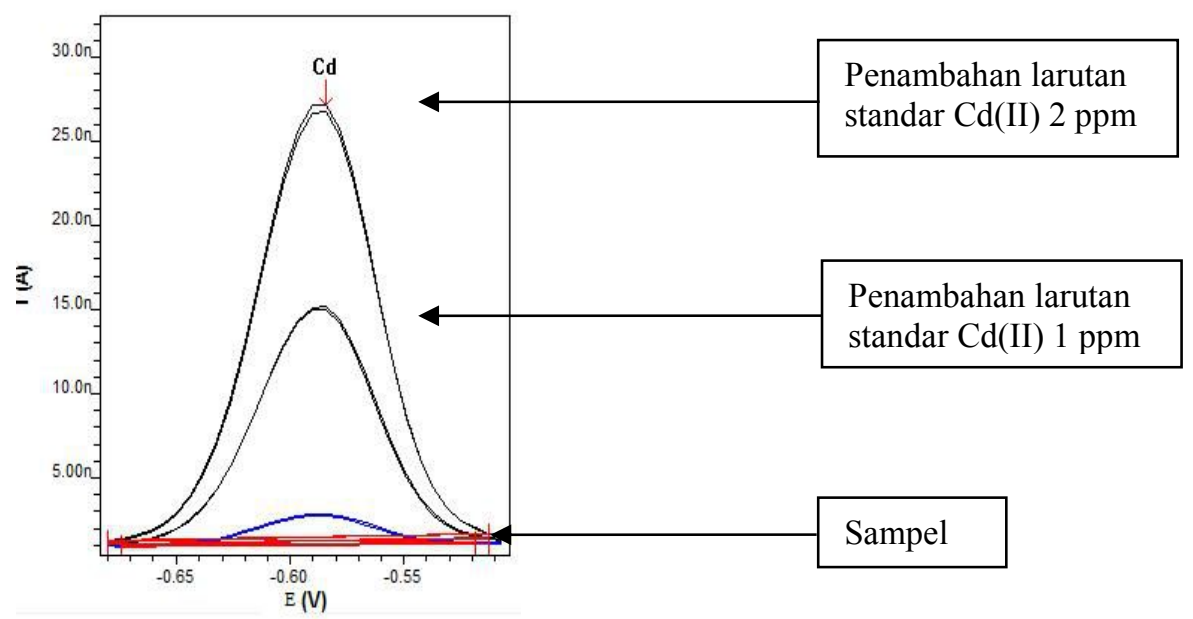

Gambar 7. Voltamogram sampel air lubuk minturun dengan metoda standar adisi 


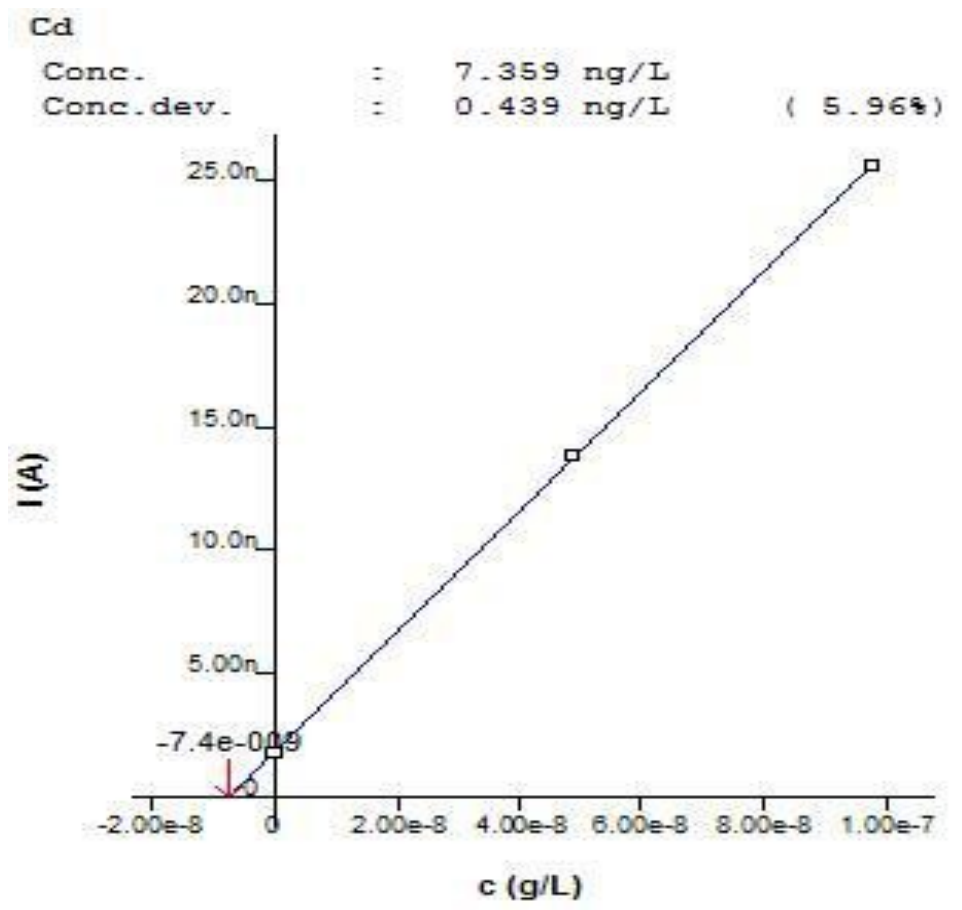

Gambar 8. Kurva standar adisi sampel Lubuk Minturun

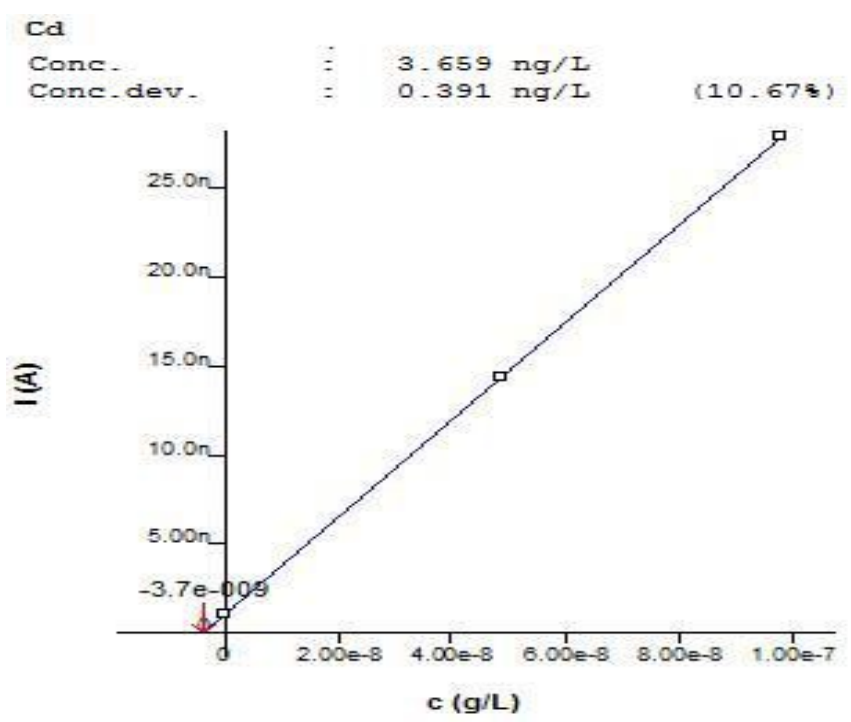

Gambar 9. Kurva standar adisi sampel Muara.

Tabel 1. Hasil Perolehan Kembali Cd(II)

\begin{tabular}{ccccc}
\hline No & $\begin{array}{c}\text { Konsentrasi } \\
\text { ditambahkan } \\
(\mathrm{ng} / \mathrm{L})\end{array}$ & $\begin{array}{c}\text { Konsentrasi sampel } \\
(\mathrm{ng} / \mathrm{L})\end{array}$ & $\begin{array}{c}\text { Kosentrasi setelah } \\
\text { ditambahkan } \\
(\mathrm{ng} / \mathrm{L})\end{array}$ & $\begin{array}{c}\text { Perolehan } \\
\text { kembali } \\
(\%)\end{array}$ \\
\hline 1 & 2 & 3,659 & 5,160 & 91,18 \\
2 & 4 & 3,659 & 7,359 & 96,08 \\
3 & 6 & 3,659 & 10,613 & 109,87 \\
\hline \multicolumn{5}{c}{ Jumlah } \\
\hline
\end{tabular}




\section{DAFTAR PUSTAKA}

1. A. Rahman, Kandungan Logam Berat Timbal $(\mathrm{Pb})$ dan Kadmium (Cd) pada Beberapa Jenis Krustasea di Pantai Batakan dan Takisung Kabupaten Tanah Laut Kalimantan Selatan, Bioscientiae, 3: 93-101, (2006).

2. K. L. Seung, S. C. Hee, Spectrophotometric Determination of Cadmium and Copper with Ammonium Pyrrolidinedithiocarbamate in Nonionic Tween 80 Micellar Media, Bull. Korean Chem. Soc, 22: 463-466, (2001).

3. G. Gisele, Bortoleto, T. Greice, Macarovscha, C. Solange, Determination of Cadmium by Flame-Atomic Absorption Spectrometry After Preconcentration on Silica Gel Modified with Cupferron, $J$. Braz. Chem. Soc., 15: 313-317, (2004).

4. J. Chwastowska, W. Skwara, E. Sterliñska, J. Dudek, M. D' browska, L. Pszonicki, GF AAS Determination of Cadmium, Lead and Copper in Environmental Materials and Food Products after Separation on Dithizone Sorbent, Chem. Anal. (Warsaw), 53: 887, (2008).

5. NN. Method 6200, Field Portable x-ray Fluorescence Spectrometry for the Determination of Elemental Concentrations in Soil and Sediment, 2007.

6. W. Joseph, Analytical Electrochemistry, John Willey \& Sons Inc. Publications, 2000, 60-84.
7. L. Meijes, Handbook of Analytical Chemistry, Mc.Grow Hill, New York. 1962.

8. Plambeck, Electroanalytical Chemistry, Willey-Inter Science, 1962.

9. F. Shemirani, M. Rajabi, A. Asghari, M. Reza Milani, Simultaneous Determination of Taces of Cadmium and Zinc by Adsorptive Stripping Voltammetry, Canadian $J$. of Analytical and Spectroscopy, 50: 175-181, (2005).

10. A. Babaei, E. Shams, and A. Samadzadeh, Simultaneous Determination of Copper, Bismuth and Lead by Adsorptive Stripping Voltammetry in the Prescence of Thymolphtalexone, Anal.Scie. The Japan Society for Analytical Chemistry, 22: 955959, (2006).

11. A. A. Ensafi, T. Khayamian, A. Benvidi, E. Mirmomtaz, Simultaneous Determination of Copper, Lead and Cadmium by Cathodic Adsorptive Stripping Voltammetry using Artificial Neural Network, Anal. Chem. Acta, 561: 225-232, (2006).

12. C. Li, B. D. James, J. Rumble, R. J. Magee, Adsorptive Stripping Voltammetry of Some Trace Elements in Biological Samples. I. Cadmium and Zinc, Micro Chem. Acta, 96: 175-182, (1988).

13. J. C. Miller, J. N. Miller, Statistik untuk kimia analitik, edisi ke-2, penerbit ITB, Bandung, 1991, 52-66. 